\title{
Managing or restricting movement? Diverging approaches of African and European migration governance
}

\author{
Franzisca Zankere
}

\author{
Correspondence: \\ franzisca.zanker@abi.uni-freiburg.de \\ Arnold Bergstraesser Institute at the \\ University of Freiburg, Windausstr. \\ 16, 79110 Freiburg, Germany
}

\begin{abstract}
Though a common EU-African agenda of dealing with migration goes back at least a decade with bilateral, regional and continental approaches, it has gained in visible importance in recent years. But what are the actual approaches and does the rhetoric they evoke speak to their actual practice? Unpacking 76 policy documents relating to the governance of migration from African and European institutions between 2005 and 2016, the paper finds that the rhetoric is diverting in itself (both managing and controlling mobility) but also surprisingly similar. There is however a pronounced difference between a management-orientated discourse and the restriction-orientated practice. This is likely tied to hidden agendas: for the EU moving migration controls away from Europe's borders to the African continent, whilst simultaneously strengthening the rhetorical EU-African partnership. The rhetorical mirroring in African documents may also be an attempt by African states to achieve leverage in an otherwise asymmetric relationship.
\end{abstract}

Keywords: Migration governance, EU-Africa relations, Migration-development nexus, Securitisation, Mobility

Though the development of common approaches to migration between African countries and the EU go back a long time, with numerous bilateral, regional and continental policies, the topic is facing renewed attention. In 2015, more than 60 heads of states and government met in Valetta for the first summit between the EU and African partners solely dedicated to the topic of migration. Since then further events have confirmed this area as one of the most important policy issues on the joint agenda including the 5th EU-Africa Summit in November 2017. But these processes have been criticised for the asymmetry in favour of European interests compared to those of their African partners. Though a gap between political rhetoric and implemented policies is by no means unusual (e.g. Hampshire, 2016), this has not been considered in any depth in terms of the relationship between Africa and the EU on migration governance. This paper aims to comprehensively map the approaches to migration governance of African and EU stakeholders, by considering both the rhetorical stances of policies and their implementation in practice. The rest of the paper is structured as follows: in a first section, the paper argues that migration is mainly governed in a contradictory manner with the aim of either easing mobility (for development) or controlling migration. The section also briefly introduces the major policy frameworks for

(C) The Author(s). 2019 Open Access This article is distributed under the terms of the Creative Commons Attribution 4.0 International License (http://creativecommons.org/licenses/by/4.0/), which permits unrestricted use, distribution, and reproduction in any medium, provided you give appropriate credit to the original author(s) and the source, provide a link to the Creative Commons license, and indicate if changes were made. 
governing migration. The main part of the paper unpacks the rhetoric of 76 documents relating to the governance of migration from African and European institutions. The section finds that though African policy instruments favour easing mobility restrictions for development, the EU-led documents also show a strong rhetoric in favour of developing legal migration. Nonetheless, they speak to different kinds of mobility: For the EU institutions mobility is short-term and circular, often within Africa and highlights a migration-development nexus whereby development prevents migration. African rhetoric favours easing mobility for development. Most surprisingly, in terms of controlling migration, the African documents were equally strong in underlining controlling migration.

The paper goes on to consider the practice of migration governance, showing that EU policies were however more securitised in practice than their much more reserved rhetoric. The paper concludes that the rhetoric is surprisingly similar though it mirrors both the aim of managing and restricting mobility, potentially a juxtaposition. There is however a pronounced divergence between a management-orientated discourse and the restriction-orientated practice. The gap between rhetoric and practices serves the European interests of moving migration controls away from Europe's borders to the African continent, whilst simultaneously rhetorically strengthening the EU-African partnership. Moreover, the commonalities between the rhetorical stances of the two continents may be an attempt by African states to achieve leverage in an otherwise asymmetric relationship.

\section{Migration policies - to ease or control?}

The governance of migration has long received attention not only on the world political stage but also in academia. Though migration is multifaceted and is difficult to define in any categorical manner, the mobility of persons no doubt has effects for the development of a country as well as potentially for their security as a sovereign state. Though many governing approaches exist, with arguably limited success (Castles, 2004), governance of migration juxtaposes two - potentially competing - visions, namely regulating forms of mobility compared to controlling irregular migration. On the former, migration has become increasingly accepted as a 'tool' for development. Resulting from this is for example the importance of remittances, especially in Africa (Lavenex \& Kunz, 2008; Van Criekinge, 2016). Thus, policies in this direction will seek to ease mobility (and lower transaction costs of remittances). Yet, a positive migration-development nexus is by no means widely accepted in practice. The relationship between migration and development is circular and highly complex, incorporating both positive and negative impacts (e.g. Clemens, 2014). Out-migration may lead to more remittances, but also brain-drain of professionals. Moreover, development may also be considered as a territorialised process (decoupled from globalisation), resulting in migration policies that favour development at home in order to 'prevent' migration (Nijenhuis \& Leung, 2017).

Either way, policy makers often see development as a trade-off to security concerns (challenging this see Lavenex \& Kunz, 2008). ${ }^{1}$ In the EU the securitised vision of migration goes back to the 1980s, and it has continuously been reinforced since then. Using the alleged fear that immigration may infringe on public order, borders are secured and migrants become securitised objects. Fundamentally, the securitised approach juxtaposes the freedom of movement within Europe (through Schengen) with stronger borders and an 
externalisation of migration controls (e.g. Andersson, 2016; Bourbeau, 2015; Völkel, 2014). Drawing from these debates, only very briefly touched upon here, would suggest that African states and institutions would focus on easing mobility as primary beneficiaries of migration for development and the EU and European countries on controlling (irregular) migration in an increasingly securitised-migration context.

When it comes to migration governance in and with African countries, research tends to be geographically and thematically limited, focusing only on one region or type of migration category, e.g. forced versus 'voluntary' (usually labour) migration (e.g. Brachet, 2010; Rwamatwara, 2005). Moreover, whilst the literature on migration patterns in Africa repeatedly highlights the fact that most African migration is inner-African, this is not reflected in the literature on the topic, which largely focuses on 'South-North' migration (Flahaux \& De Haas, 2016). Thus, a research gap exists in considering migration governance between Europe and Africa and especially within Africa. Understanding the rhetoric and practices of migration patterns of both continents is fundamental to improve their relationship and future cooperation. A number of policy initiatives exists and acknowledging the fact that migration policies should be addressed transnationally (Castles, 2004), the various global, regional and bilateral policy instruments are considered below.

Globally, in Africa the AU has increasingly supported the freedom of persons across the continent and adopted an AU Migration Policy Framework for Africa in 2006, with a protocol on the freedom of movement formally adopted in early 2018. On the European side, an overarching framework for the external migration and asylum policy of the EU was launched in 2005 and further clarified in 2011. This Global Approach to Migration and Mobility (GAMM) follows four objectives (of equal importance): managing legal migration; preventing and combatting irregular migration; maximising the development impact of migration and promoting international protection. Further, EU-Africa Summits with heads of states and government take place every 3 years. These have also informed migration governance resulting in for example the partnership on Migration, Mobility and Employment (2007) and an action plan on migration and mobility (2014). Most of the policy making on migration governance however takes place on a regional and bilateral level.

Regarding regional instruments in Africa, the Economic Community of West African States (ECOWAS) comes at the forefront, who have enshrined freedom of movement including the right of entry, establishment and residency in a series of protocols since 1979 including a memorandum on refugees from 2007. The Intergovernmental Authority on Development (IGAD) has also developed a comprehensive regional migration policy framework. ${ }^{2}$ An AU Horn of Africa Initiative was launched in 2014 to respond to human trafficking and people smuggling on the continent. From the EU side, the strongest instrument is the Rabat process, launched in 2006, which offers space for an operational partnership on migration between the EU, with African countries along migration routes from and via North, West and Central Africa. Additionally, the Khartoum Process was launched in 2014 and primarily aims to tackle human trafficking and the smuggling of migrants in countries of origin and transit in the Horn of Africa. A last regional approach towards migration is the African, Caribbean and Pacific Group of States (ACP) - EU dialogue, with a Joint Declaration on migration and development adopted in June 2010. With 
negotiations currently ongoing in light of a new agreement needed for 2020, migration is set to take on a more prominent role.

Lastly, the EU has developed bilateral instruments, the strongest commitment to joint migration governance. Firstly, mobility partnerships are the main comprehensive and long-term bilateral framework for facilitating policy dialogue and operational cooperation on migration management with third countries. Such mobility partnership exists in Africa with Cap Verde (2008), Morocco (2013) and Tunisia (2014). Less commitment is expressed through a Common Agenda for Migration and Mobility, which signal a wish to advance cooperation on migration in the long-run, which have been signed with Nigeria and Ethiopia in 2015. Most recently, in June 2016, the Migration Partnership Framework was launched. The idea is to reach compacts with partner states that combine migration policies with other areas of competence of the EU, including development aid, trade, energy and security. Mali, Nigeria, Niger, Senegal, and Ethiopia are priority countries for partnership compacts in Africa. The rhetoric of these poliy documents is outlined below.

\section{The rhetoric of migration: managing mobility}

In line with both development and security-orientated forms of migration governance both easing mobility and controlling movement are considered in the content analysis. The section finds that though African policy instruments favour easing mobility restrictions for development, the EU-led documents also show a strong rhetoric in favour of developing legal migration. Nonetheless, they speak to different kinds of mobility: For the EU institutions mobility is restricted to the African continent and the documents highlight a migration-development nexus whereby development prevents migration. In african documents, the rhetoric highlighted easing mobility for development. Surprisingly, in terms of controlling movement an unexpected level of wanting to control migration came out of the African documents.

The paper applies a content analysis methodology, based on the analysis of policy documents and EUTF projects (further below). The aim of the methodological approach is to assess how frequently and in what ways policy documents speak of migration in terms of easing or restricting mobility. Texts were interpreted qualitatively using codes, deduced from the debates on migration governance. The codes were inductively revised after coding an initial batch of documents. In addition, a limited quantitative analysis took place, through a frequency count. ${ }^{3}$ The way words are used (in which context and considering their polysemy) further contextualises their meaning. This gives an insight into priorities and directions of the formal elite-level processes. Of course this approach does not allow for an insight into the negotiation processes behind the policy formulations nor what is happening at a less formal level of migration governance, no doubt relevant (e.g. Rother \& Piper, 2015). Nonetheless, it serves as an indication for understanding commonalities and divergences between EU and African interests in migration governance.

The starting date of the observation period is tied to the European GAMM, which was initially launched in 2005 and ends in 2016 when the new Partnership Framework was launched. The paper analyses a total of 76 documents, see Table 1 below, 32 of which are African documents, with 20 and 24 documents from the EU and EU-African 
Table 1 Overview of Documents used for the content analysis

\begin{tabular}{lllll}
\hline Policy institutions & \multicolumn{2}{l}{ Approach } & Total \\
\cline { 2 - 4 } & Bilateral & Regional & Global & 32 \\
\hline African & $/$ & 16 & 16 & 24 \\
EU-African & $/$ & 13 & 11 & 20 \\
EU-only & 15 & 3 & 2 & 76 \\
Total & 15 & 32 & 29 & \\
\hline
\end{tabular}

policy institutions respectively. Note however that the EU-African documents are still primarily under EU penmanship (see also Collyer, 2016). Most of the documents are the regional or global level. The analysis was carried out with MaxQDA.

\section{General approaches towards migration governance}

Before considering the two approaches of easing and controlling migration in more detail, a few more general remarks on the understanding of migration. ${ }^{4}$ One policy area which everyone seems to agree on is the lack of reliable data and the need to build up better information and data on migration, including so-called migration observatories (e.g. B3, see Additional file 1 for all the document codes). Secondly, there is a broad rhetorical commitment to protecting the human rights of all migrants. This is strongest in the African documents, with a statement by Nkosazana Dlamini Zuma, as AU Chairperson at the time of the Valetta Summit noting for example ' ... processing centres, or whatever they may be called, are de facto detention centres that will constitute a serious violation of human rights and re-victimization of migrants' (emphasis added; A1). Similarly, the AU Common Position on migration for example states that the 'fight against illegal or irregular migration must be waged within the context of strict observance of human rights and human dignity' (emphasis added; A6). An almost identical phrase regarding the observation of human rights appears in the Rabat Three-Year Cooperation Programme (Bb11). In fact, if we search for right"AND dignity within one sentence, it appears twice on average in the EU-African documents, compared to 0.8 times in the African documents (and 0.7 times in the EU ones, c.f. Table 2). Nonetheless, though more frequent, the wording is much weaker, often used like a side-note, e.g. 'a coherent, credible and effective policy with regard to the return of illegally staying third country nationals, which fully respects human rights and the dignity of the persons concerned' (emphasis added; Ccc15).

Not as widespread, but still common is a general agreement that third actors need to be included in addressing migration. Diaspora members are frequently linked to development, but also wider calls such as for 'socio-cultural structures for migrants ... increasing their capacity to undertake development actions' (Bb11). In addition, there is a tendency to opt for policy coherence, especially when it comes to 'mainstreaming of migration in development thinking' (e.g. C2), but also includes calls to include strong asylum protection strategies in in national poverty reduction strategies (e.g. B2) or the coherence between security and migration policies (e.g. Aa10). This has become most strongly apparent in recent EU policies since the Partnership Framework, whereby development cooperation has become explicitly tied to migration goals (e.g. Ccc15). 
Table 2 Frequency counts for rhetoric on the different approaches to migration governance

\begin{tabular}{lllll}
\hline & & $\begin{array}{l}\text { African documents } \\
\text { (32 documents) }\end{array}$ & $\begin{array}{l}\text { EU-Africa documents } \\
(24 \text { documents })\end{array}$ & $\begin{array}{l}\text { EU only documents } \\
\text { (20 documents) }\end{array}$ \\
\hline General Approaches & mixed migration & $0.6(20)$ & $0.25(6)$ & $0.1(1)$ \\
& right* AND dignity & $0.8(24)$ & $2(48)$ & $0.7(14)$ \\
& partnership & $3.3(104)$ & $16(385)$ & $16.3(326)$ \\
Regulating Migration & Legal AND migra* & $4(129)$ & $9.3(222)$ & $10.3(205)$ \\
& NOT illegal & & & \\
& Circular AND migration & $0.5(15)$ & $2.7(65)$ & $2.7(54)$ \\
& mobility & $5.4(173)$ & $6.3(152)$ & $12.3(245)$ \\
& mobility AND legal & $0.8(25)$ & $2.5(60)$ & $3.3(65)$ \\
Controlling Migration & irregular & $4.9(158)$ & $4.5(107)$ & $8.5(170)$ \\
& fight* OR combat* & $3.6(114)$ & $8.3(199)$ & $5.1(101)$ \\
& border management & $3.8(121)$ & $2.6(63)$ & $2.8(56)$ \\
& OR control & & $12.2(292)$ & $14.4(247)$ \\
& traffick* OR smugg|* & $28.4(910)$ & $5.2(126)$ & $8.7(173)$ \\
& Return & $4.3(136)$ & $2.8(68)$ & $3.3(66)$ \\
\hline
\end{tabular}

*is used to search for any word that begins with the root/stem of the word truncated by the asterisk. E.g. migrant, migration.

In terms of defining migration more generally, despite the increasing attention to the reductive nature of artificially separating migrants from refugees, the term 'mixed migration' is used infrequently (see Table 2). The term appears most often in the African documents, which tend tend to be quite elaborate in defining migration, e.g. as 'the search for safety, a better life, better climates, markets, goods to trade - [it] is as old as humanity itself' (A1). Though the EU-led GAMM indirectly concedes to the complexity of defining migration, stating that their approach 'should ... be migrant-centred. In essence, migration governance is not about 'flows', 'stocks' and 'routes', it is about people' (C2), the African documents tend to display more complexities in their definitions.

In terms of the predominance of inner-African migration, the African documents largely speak of migration within the continent, though some do acknowledge migration outside the continent, including increasingly to the Middle East (e.g. A6 or Aa9). The EU and EU-African documents also acknowledge this geographic concentration of migration patterns, stating for example 'inter- and intra-regional migration in developing regions far exceeds migration to the EU' (C2) or 'acknowledging that migratory movements occur essentially within Africa ...' (B2). The EU-led documents do however still tend to focus on migration towards Europe, or when they refer to migration within Africa they always add the South-North dimension in addition. Thus, the previously cited document continues for example, ' ... and also towards developed countries' (B2).

To sum up so far then, there are some commonalities (better data, protecting the human rights of migrants, third actor involvement, policy harmonisation), but the differences also appear. The EU has the most expansive approach on how to harmonise migration policies, and the African documents are more comprehensive in their definition of migration and more overtly mention the human rights of migrants. The EU-led documents on the whole are more geared towards Northwards migration, though they by no means ignore that most African migration is within the continent. Now the two governance approaches of easing and controlling migration will be considered in more detail. 


\section{Unpacking the migration-development nexus}

A consequence of accepting a positive relationship between migration and development would be a policy approach that highlights easing mobility through legal avenues of migration. Thus in order to unpack the approaches towards the migration-development nexus amongst and between the African and European partners, the relationship between migration and development via mobility and legal avenues for movement is analysed in the following.

First of all, both the EU-led and the African documents are open to the idea migration can be good for development. African documents notably refer to the 'untapped potential' [of migration in Africa] (A5) or reiterate the role of 'migrants as agents of innovation and development' (A2). They are especially focused on how to better regulate and lower the costs for remittances (e.g. Aa14) and more generally advocating for labour rights (e.g. A3). The importance of remittances are also widely recognised by EU and EU-African documents (e.g. Ccc7, B2). One of the ACP-EU Document takes this further, stating that 'better management of migration may generate very important gains, perhaps more important than the removal of world trade barriers' (Bb3). This strong statement does not appear elsewhere, and also reiterates a point made in all of the documents. Namely, there is an urgency for migration to be well-managed in order to reap the benefits for development, since it is the 'good governance of migration [that] will ... bring vast development benefits' (C2). Thus, the emphasis is on regulating mobility in order to tap into the development-migration nexus.

Regulating mobility is at least in part linked to opportunities for legal migration. Though legal migration was in fact a priority for African states at the Valletta Summit (see A2), the term legal (and migration) appears on average 9-10 times for each EU-led document, compared to only 4 times for the African ones, see Table 2.

Generally the documents, including the African ones, are however quite vague when it comes to legal migration. For example a Roadmap (2014-17) from the fourth EU-Africa summit refers to legal migration as the 'promotion of alternatives to irregular migration' (B8), without detailing what these alternatives may be. When they are more specific the primary form of legal migration is through education, and only followed by labour migration (e.g. B10). Education measures include scholarships and making training and certificates more compatible (across Africa, e.g. A10). The preference for education also signals the preponderance of temporary understanding of legal forms of migration. Here the understanding of legal migration also begins to diverge, with EU-led documents especially strong on advocating temporary mobility. Circular migration appears in European-led documents 2.7 times on average per document, compared to only 0.5 times in the African ones, see Table 2. The Mobility Partnership with Cap Verde for example mentions 'legal migration, in particular circular and temporary migration' or calls for 'measures for temporary workers and encourage circular migration of workers' (Ccc1). Whilst the aim is to benefit from temporary workers such as health workers (C1), African documents speak of temporarily differently, through creating 'an environment conducive to circular migration (brain circulation)' (A6) whereby the emphasis is to regain from return highly-skilled diaspora (e.g. Aa9).

In sum therefore, there is a strong rhetoric for legal migration - especially in the EU-led documents, but it tends to be vague, and for the EU-led documents highlight the temporary nature of mobility. More generally, this is reflected in the understanding of 
mobility itself. A preliminary illustrative view of mobility shows that it is by no means disregarded in the European context - it appears on average 12.3 times in EU documents compared to the average of 5.4 times in the African documents (see Table 2).

If we take a closer look however, acknowledging the polysemy of a concept like mobility, we find that on the whole African rhetoric favours easing mobility for development (see also Van Criekinge, 2016) whilst the EU institutions are geared towards regulating mobility in conjunction with territorially-bounded development to prevent migration. This highlights diverging meanings of mobility, with the latter approach in fact far more restrictive.

African documents tend to consider mobility as the free movement of people. Consequently, mobility is described in terms of harmonization of educational standards and, as a first step towards African passports and easing up of visa requirements. This mobility or free movement underpins the very foundation of the continent in the coming years and is ' ... a crucial element for deepening continental integration and unity in the spirit of Pan-Africanism' (A11). Interestingly, the ECOWAS Common Approach on Migration notes that free movement reduces migratory pressure beyond its boundaries (Aa6). This is where the European-led documents tap into.

Though the EU documents refer to mobility, they mostly do so in conjunction with legal migration or as something to be (well) managed (Cc3), see also Table 2. Moreover, there is a surprisingly strong focus on mobility and labour rights in EU-led documents within Africa (e.g. B2, Bb11). This can be linked to a territorialised form of development to prevent migration (see Nijenhuis \& Leung, 2017). For example, in Article 13 of the Cotonou Agreement, the nexus between development and migration is highlighted as aiming to 'normalise migration flows' though reducing poverty (Bb4). Similarly, the Rabat Declaration which states that 'concerted action on the root causes of migration [is required], in particular through the implementation of development projects in Africa' (emphasis added; Bb10). In addition, the documents call for encouraging private investments in the countries of origin (e.g. Ccc15), promoting Foreign Direct Investment to 'generate employment and reduce migration outflow (B2), capacity building in the health and education section (e.g. B2), social protection (B5) and more recently the importance of resilience and strengthening livelihoods, which has become a core of the EU Trust Fund projects (e.g. B9, see also below).

In part, African documents also prescribe to the benefits of such territorially-bounded development, in response to some of the negative consequences of mobility. The AU Common Position on migration for example states that 'poverty is one of the main causes of migration. Creating development opportunities in countries of origin would mitigate the main reasons for young people to engage in migration, thereby also dealing with the problem of brain drain' (A6). Nonetheless EU-led documents are much clearer in advocating for regulating mobility (with temporary measures) and also development in Africa to prevent migration. African rhetoric favours easing mobility for development.

In sum, mobility and legal migration is universally enshrined, and in fact more prominently in the EU-led documents. However, there are nuances to this. There may be a strong rhetoric for legal migration, but it tends to be vague, and frequently refer to education programmes or to legal migration within Africa. Moreover, African documents are more pointed towards easing mobility and the development potential of migration and the EU-led documents geared towards regulating mobility in conjunction with 
territorialised development to prevent migration (see also Raineri \& Rossi, 2017). This regulatory approach already signals a preference towards control, i.e. using development as an incentive to stop irregular migration.

\section{Unpacking the migration-security nexus}

One of the goals in the Valetta Action Plan, 'preventing and fighting irregular migration,' is clearly one of the major priorities from the European side (B11). Yet, much of the measures taken in this regard as well as such securitized language can be found in all of the regions. The documents in fact universally focus on the potentially destabilizing impact of unmanaged migration on (national/regional/international) security (e.g. A4) and rhetorically commit to the fight against 'illegal' or 'irregular' migration (e.g. A5). Thus, a migration-security nexus is made by all with an emphasis on controlling irregular migration.

The term irregular is used most frequently in the EU-only documents (8.5 times on average), but is more frequent in the African documents (4.9 times on average) than in the EU-African ones (4.5 times, see Table 2). Interestingly, the term becomes more frequent over time, as does other language such as fighting or combatting ${ }^{5}$ (irregular migration), both peaking in 2015 at the time of the Valetta summit (see Fig. 1).

Much depends however on how these actors understand the securitised terms they envisage. Carling and Hernández-Carretero categorise preventative migration measures (to manage unauthorised migration from Africa) into direct control, deterrence and dissuasion (2011). Dissuasive measures are broadly accepted by all sides and include foremost creating jobs in order to reduce irregular migration (e.g. A6, B7, Ccc15). Another major policy area that everyone can agree on is better data-collection (including improved national civil registries) and providing better information to (potential) migrants about the dangers of the journey (e.g. Ccc15 Aa15, Aa12, Ccc5).

As for control and deterrence measures, here there is first of all a dependency relationship between the EU and the African institutions. As such, policy documents iterate that 'particular attention should be paid to capacity-building to strengthen capacity in migration management' (Ccc15), and include better legislation, improving coordination

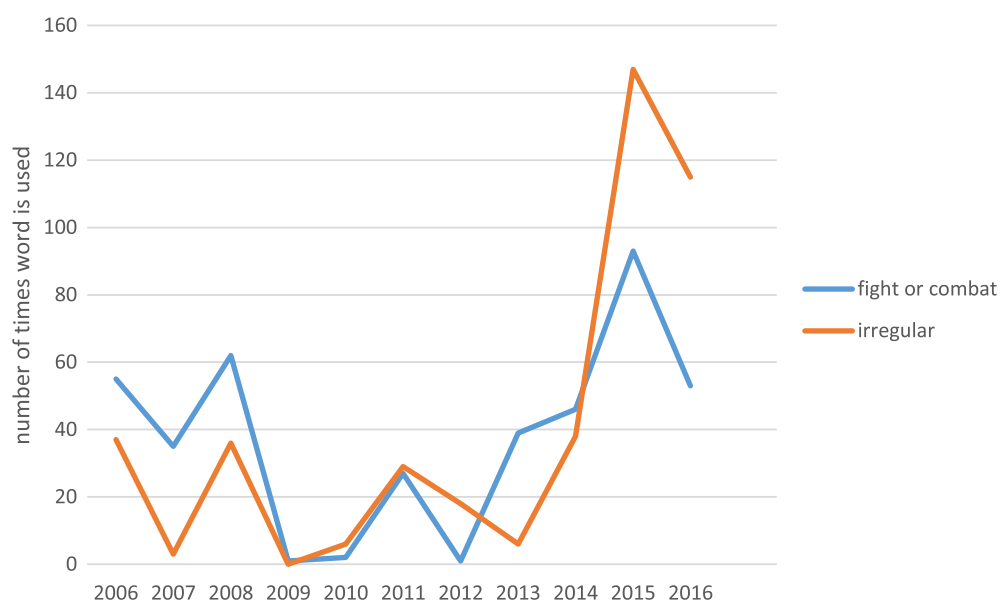

Fig. 1 Use of securitised language in the policy documents over time 
and information flows and the secondment of European Migration Liaison Officers to key partner countries in Africa (e.g.A5, Ccc6, Ccc15). Aside from concrete measures like the 'multi-purpose centre' in Agadez (Niger) for registering (and returning) migrants (B11) and the Common Security and Defence Policy missions in Mali and Niger (C1), there are two major measures where the security-migration is addressed through control/deterrence - border management and addressing smuggling and human trafficking.

In terms of border management, the documents again envision what essentially comes down to improving the capacities of the African partners such as upgrading the 'capacities of border officials, physical infrastructure and enhancing communication and cooperation between origin, transit and destination countries' (A5), joint patrols (e.g. Ccc15) and improved intelligence-sharing between countries (e.g. B11). Yet border management is also prioritised in the African documents - it appears as the second policy strategy out of a total of nine in the AU Migration Policy Framework (A5). It is however discussed in relative complexity:

'Border management systems are coming under increasing pressure from large flows of persons, including irregular and "mixed flows," moving across regions and/or national borders ... A key challenge is therefore to ... meet ... humanitarian obligations to refugees ... while concurrently addressing the need to manage borders effectively' (A5).

In the GAMM the second out of four equal pillars is subtitled 'saving lives and securing external borders', though the focus is on the latter and yet again on 'strengthening the capacity of third countries to manage their borders' (C1). Border management or control appears on average 3.8 times for each African document, and around 2.7 times for the EU-led ones. The securitised language is thereby by no means the exclusive prerogative of the EU-led processes, the African ones also speak to it. There is however a relationship of dependence and the African documents frequently reiterate the rights of those in need of protection when crossing borders.

Even more prominent than border control is the common enemy of human traffickers (and smugglers). Most document highlight the need to protect victims of trafficking. The Declaration of the Fourth EU-Africa Summit from 2014 for example states that, 'we reiterate our unambiguous commitment to continue fighting trafficking in human beings, which is a new form of slavery' (B6). Similarly, the GAMM here states: 'Action to fight criminal networks of smugglers and traffickers is first and foremost a way to prevent the exploitation of migrants by criminal networks' (C1), also adding however that it is 'a disincentive to irregular migration' (Ibid). Therefore approaching human trafficking is not merely a protective tool, but another control / deterrence mechanism. Solutions to tackle trafficking include data collection (e.g. Bb8), cooperation, intelligence sharing and capacity-building (e.g. B11), strengthening policy frameworks and implementation and prosecution of traffickers (B8). Recently, the EU has turned to 'the creation of alternative income' to replace the 'migration industry' (e.g. Ccc7, Ccc12).

Yet again, the term trafficking or smuggling is used on average more than 28 times for each of the African documents compared to only just over 12 times for the EU-led ones, see Table 2. This in part due to the preponderance of trafficking and smuggling 
in regional networks, in fact the terms are mentioned over 700 times in African regional documents or in $84 \%$ of all mentions in African documents, see Table 3 below. This is mainly within the IGAD framework.

The EU preference for controlling (and deterring future) migration is most obviously shown through their attitude towards return. The EU prioritisation of return can be seen by the fact that return is used on average 4.3 times in African documents, 5.2 times in the EU-African ones and a strong 8.7 times on average in each of the EU documents, see Table 2. Increasingly, returns are highlighted as a priority (e.g. Ccc15) including within Africa (Bb11). The link between return as a way to achieve the goal of preventing and combatting irregular migration is made explicit in for example the EU-Ethiopia Common Agenda on Migration (Ccc5) or as an important tool in managing migration in the Dakar Strategy (Bb12). In terms of their rhetorical commitment, the EU-led policy are careful to favour voluntary returns, with the two appearing within one sentence on average 3.3 times compared only just over once in the African documents (see Table 2). In some documents this is voiced as a 'preference' for voluntary return (e.g. Ccc15) or 'the emphasis [is] placed on the forced return of illegal migrants as the last resort in a process which includes the promotion of voluntary return' (Bb6).

In order to regulate returns, the policies (and here they all concur) call for creating standards and procedures for 'effective, sustainable return' (i.e. Cc1) or a coherent policy (e.g. Ccc15). The strongest agreement between the countries is on the necessity of reintegration support once the returnees are back in their countries of origin (e.g. Aa8, Cc1, Ccc9). Documents also speak of improved cooperation, especially on identification and issuing travel documents (e.g. Ccc8). There is a particular focus on negotiations for return and readmission (e.g. Ccc7), which also include negative incentives if cooperation on returns is lacking (Ccc15). This principle is not new, a link between readmission agreements to visa facilitations agreement already dating back to the GAMM (C2) or the Valetta Action Plan for 2015 (B11, see also Nijenhuis \& Leung, 2017; Van Criekinge, 2016). Nonetheless, in the European Agenda on Migration from the same year, the language is already more forceful, stating that one aim is to 'ensure a humane and dignified treatment of returnees and a proportionate use of coercive measures, in line with fundamental rights' (emphasis added, C1).

To sum up, though the discussion on return highlights the EU preference for controlling migration, the overall securitised rhetoric is subtler and by no means an overwhelmingly European one. Issues of border control, and dealing with trafficking and smuggling are also highlighted in the African documents, at times even more frequently. This is due in part to an overwhelming regional prioritisation (through IGAD) and also highlights the need to protect migrants at the border. Moreover, the relationship is frequently constrained by a form of dependence - the African states receive capacity and aid in order to strengthen their borders. In rhetorical language, the EU is strong on highlighting legal migration over controlling and restrictive measures (see

Table 3 Use of 'trafficking or smuggling' across approaches (main approach in bold)

\begin{tabular}{lllll}
\hline & Bilateral approach & Regional approach & Global approach & Total \\
\hline African documents & $/$ & $\mathbf{7 6 2}(\mathbf{8 4 \% )}$ & $148(16 \%)$ & 910 \\
EU-African documents & $/$ & $107(37 \%)$ & $\mathbf{1 8 5}(\mathbf{6 3 \% )}$ & 292 \\
EU documents & $\mathbf{1 8 6 ( 7 5 \% )}$ & $10(4 \%)$ & $51(21 \%)$ & 247 \\
\hline
\end{tabular}


also Mangala, 2013). Thus overall, the rhetoric of the documents go in the direction of managing migration - both legal and irregular - whether in the interests of easing mobility or in order to reduce migration Northwards. If anything, a rhetoric of control came out more indirectly, like through the regulatory approach towards mobility. The practice of migration approaches also finds a strong preference for restricting migration, discussed next.

\section{The practice of migration: restricting movement}

As the paper will show in the following, implementation of the African and even the EU-African policies is largely limited, despite the often strong rhetorical stance they take in terms of easing mobility and restrictive measures to curb irregular migration. For the EU, there is a more concrete policy implementation in recent years, primarily through the European Trust Fund projects. In practice like in its rhetoric the EU prioritises irregular migration, but unlike its rhetoric concrete action especially on legal migration is missing. In fact, the EU practice points to a strong preference for restricting migration.

When it comes to the African rhetoric on mobility and development, implementation continues to falter. This is not least due to weak frameworks and lack of technical capacity. The AU Migration Policy Framework is not legally binding and is therefore a rather weak instrument. Moreover, by 2016, three people were working on migration in the AU Department of Social Affairs, compared to an estimate amounting to over 400 in the EU (Witt \& Both, 2016). A follow-up from the Migration Policy Framework, the AU adopted a Freedom of Movement protocol in early 2018 as a first step towards a treaty enshrining such mobility. But the implementation depends - like for everything else - one the Regional Economic Communities (RECs) to enforce their decisions on migration. Even ECOWAS, prized as the role model for African mobility, faces implementation problems. Mobility and freedom of movement tends to be more theoretical than de jure: due to corruption at the borders, visa costs are simply replaced by (informal) fees directly payable to border controllers (Brachet, 2010). Moreover, by and large the RECs are not the implementing agents either, rather they are dependent on their member states to implement policy (Welz, 2015). This means it is up to the individual countries to translate these policies into national laws, which may lack the political will to do so.

The European-African instruments also vary in their implementation. The ACP Observatory on Migration for example was not only launched but even wrapped up a 4 year study on South-South migration in 2014 (IOM Press Release, 2014). Beyond this, despite the numerous summits and meetings, achievements are few and far between. Both the Rabat and Khartoum process have been marred by difficult political relationships between member countries (Collyer, 2016). The lack of implementation for both the African and the EU-African instruments and policies highlights the fact that perhaps migration is after all not a strong priority at a national level, despite the rhetorical commitment to addressing the issue.

For the EU the implementation has been much more successful, with a sense of urgency not least since the Valetta Summit of 2015 and the Partnership Framework of 2016 for stronger commitment. The legal framework of has FRONTEX changed, with them now being able to assist member states in returning failed asylum seekers. By 
June 2017, 12 European Migration Liaison Officers have been send to priority third countries of origin and transit and numerous identification missions have been carried out (European Commission, 2017a). Yet, the practice does not mirror the rhetoric. For example, opportunities for legal migration are limited with vague measures such as the promise to double the number of Erasmus + students introduced by Valetta. In fact, between 2010 and 2016 first time visas for employment for African citizens reduced by approximately $80 \%$ (MEDAM, 2018, p. 16). The practice firmly shows a commitment to restrict movement, as shown by the EU Emergency Trust Fund for Africa (EUTF).

\section{The EU emergency trust fund for Africa}

Launched during the Valetta Summit in November 2015, the EUTF seeks to swiftly set up projects addressing four main goals: 1) greater economic and employment opportunities; 2) strengthening the resilience of (vulnerable) communities; 3) improved migration management in countries of origin, transit and destination and 4) improved governance and conflict prevention and reduction of forced displacement and irregular migration. In total there are 108 projects approved by the EUTF Operative Committee (see Additional file 2). ${ }^{6}$

Sorting these projects further highlights the actual practice of the EU. The most funding is clearly assigned to employment and resilience (30\% of the projects respectively), with a predominant focus on jobs in the Sahel (28 projects) and on resilience (29 projects) in the Horn of Africa and North Africa.

Though part of the reason this occurs is because employment and nutrition programmes are easier to fund (Castillejo, 2016), this also highlights the preference for dealing with the causes of irregular migration instead of forced displacement. Moreover, it creates territorially bound development opportunities aimed if anything at preventing migration. Nor do the other goals overtly speak to easing mobility but rather to controlling or restricting movement, since even Goal 4 mentions reducing irregular migration. These preferences are further nuanced when considering the projects and funding proportionally. Here we can see that the average project for jobs and resilience is around $€ 9.7$ million. Those seeking to address governance and conflict prevention arguably the most complicated and enduring challenge of the four goals average around $€ 9$ million per project. In contrast stand migration management, which though there are the least projects with this specific goal - only $17 \%$ - have an average $€ 10.4$ million funding per project. In a similar study, Oxfam finds that $22 \%$ of the budget is allocated to migration management and only $13.5 \%$ to security and peacebuilding (with 63\% going to development cooperation, Oxfam, 2017) (Table 4).

Thirdly therefore, the goal of migration management corresponds with the proportionally largest projects. What do they entail? Analysing the 31 projects that aim to address the third goal of the EUTF in more detail again highlights the preference for control in EU practice. At least five projects mention a rather general variation on 'promoting strengthened migration management' at both national and local levels. More detailed targets are the development, harmonisation and implementation of migration policies ranging from human trafficking to labour laws (3 projects), fighting organised crime and human trafficking (4 projects), capacity building for managing migrant influxes ( 2 projects) and awareness and sensitisation campaigns to deter people 
Table 4 An overview of the EUTF according to region and goals

\begin{tabular}{|c|c|c|c|c|}
\hline \multirow[t]{2}{*}{ EUTF goals } & \multicolumn{4}{|c|}{ Number of projects and funding } \\
\hline & Sahel and Lake Chad & Horn of Africa & North of Africa & $\begin{array}{l}\text { Total funding and } \\
\text { projects per goal }\end{array}$ \\
\hline Goal 1: Jobs & 28 (290. 45 million) & 22 (170.38 million) & 4 (61.5 million) & $\begin{array}{l}54(30 \%) \\
\text { (522.33 million) }\end{array}$ \\
\hline Goal 2: 'Resilience' & 19 (194.85 million) & 29 (244.18 million) & 5 (75.75 million) & $\begin{array}{l}53(30 \%) \\
\text { (514.78 million) }\end{array}$ \\
\hline $\begin{array}{l}\text { Goal 3: Migration } \\
\text { Management }\end{array}$ & 19 (225.1 million) & 9 (83.83 million) & 3 (14.5 million) & $\begin{array}{l}31(17 \%) \\
\text { (323.43 million) }\end{array}$ \\
\hline $\begin{array}{l}\text { Goal 4: governance and } \\
\text { conflict prevention }\end{array}$ & 18 (190.9 million) & 21 (166.63 million) & 1 (2.75 million) & $\begin{array}{l}40(22 \%) \\
(360.28 \text { million) }\end{array}$ \\
\hline $\begin{array}{l}\text { Total funding per } \\
\text { Region }\end{array}$ & 901.3 million $€$ & 665.02 million $€$ & 154.5 million $€$ & \\
\hline
\end{tabular}

Source: Own compilation from the EUTF website, see Additional file 2

from leaving in the first place ( 7 projects). Another eight projects concentrate on rule of law, border control and enhancing security and an overwhelming 11 projects focus on improving conditions for voluntary return and reintegration. Though a few of the sensitisation campaigns make reference to legal migration - the focus of one project even being on freedom of mobility, albeit within the IGAD region (Project $n^{\circ} 102$ ) - the overall emphasis is on (voluntary) returning migrants and securing borders, thus restricting movement beyond Africa. Only two of the projects specifically target non-controlling elements such as encouraging diaspora investment. ${ }^{8}$

To sum up, through the practice of the EUTF projects a strong preference can be seen for restricting mobility, through prevention and control, by creating territorially bound development opportunities and improving management of migration long before it reaches Europe's borders. So does the EU put their money where their mouth is? To a degree yes. They rhetorically highlight irregular migration and prioritise returns. But EU policies are also more securitised in practice than their much more reserved rhetoric. Worse, their practice on legal migration stands in contrast to their strong rhetorical stances on these matters (see also Castles, 2004, p. 221). Thus, in practice like in rhetoric the $\mathrm{EU}$ priorities irregular migration, but unlike its rhetoric concrete action especially on legal migration is missing. Far from easing or even regulating mobility the practice in effect aims to restrict mobility. Scholars have already pointed to a rhetorical distancing away from a securitised vision of controlling migration by the EU, towards a more preventative 'root cause approach', which seeks to reduce push factors for migration (e.g. Mangala, 2013). This may however simply be control by other means, namely by preventing migration to Europe in the first place (see also Carling \& Hernández-Carretero, 2011).

\section{Conclusion}

Three conclusions can be drawn from the analysis of the rhetoric and practice of migration governance policies in the EU and Africa. First the rhetoric goes into diverting directions of managing versus controlling mobility. Second, though there are no doubt many subtle and unsubtle differences between the two continents there are also surprisingly similar in their rhetoric. Lastly, there is a pronounced divergence between a management-orientated discourse and the restriction-orientated practice.

The rhetoric juxtaposes both the management of mobility and the restriction of irregular migration. Moreover, there was some geographical divisions, especially with 
regards to mobility. African policy instruments favoured easing mobility restrictions for development and the EU-led documents looked to regulated, short-term mobility and preferably within Africa. The EU and Africa are far from a common approach to governing migration (see also Castillejo, 2017, p. 32). Nonetheless, there was also quite some similarities in the rhetoric. The EU was just was vocal - rhetorically - about legal migration. In addition, a surprising level of control came out from the African documents and was by no means only a European emphasis. More significantly there is an overall divergence between what is said rhetorically and what is done in practice. The rhetoric goes in the overall direction of managing or controlling migration, whereby the practice clearly seeks to restrict migration, especially towards Europe. Many scholars make the argument that there is a disjuncture between relative actual permissiveness for migration compared to highly securitised discourses (Andersson, 2016; De Haas, 2008). In contrast, this paper shows that EU policies with regards to governing migration are not particularly more securitised than their African counterparts, and that they are less securitised on paper than in practice. Thus the rhetoric of the documents analysed for this paper seem to be steering discursive powers away from more securitisation in contrast to much research on the topic (Bourbeau, 2015). But the aim to control migration was evident through other means, such as the regulatory approach toward mobility in conjunction with territorialised development to prevent migration. This is reiterated by the EU practice which seeks to restrict all movement, using development simultaneously to stop migration and an incentive to corporate on migration controls, thereby improving migration management (or control) long before it reaches Europe's borders (see also what Landau and Kihato call the 'containment compact', c.f. Kihato, 2018). There are several reasons for the lack of common rhetoric and the gap between rhetoric and practice.

Firstly, migration governance remains largely a national matter, which often stands in contrast to rhetorical commitments made at institutional levels. Put differently, governance approaches still follow national logics despite the transnational nature of migration (Castles, 2004; Czaika \& De Haas, 2013). This undermines the policies that are developed. For EU-led migration governance, this is by no means a new finding whereby national interests on immigration dictate policy direction and practice (e.g. Hampshire, 2016; Van Criekinge, 2016). Moreover, the focus on bilateral agreements (i.e. between the EU, member states and individual African countries) also breaks down any further chances of institutionalisation and a strengthened regional migration agenda (Bisong, 2018). The resultant inconsistency means that the "EU oscillates between bilateral and multilateral, lacks consistency and gives AU member states 'too many masters" (FES \& CCPAU, 2016). Moreover, this inconsistency is underpinned by competing and sometimes conflicting interests within the EU or between its member states (Hampshire, 2016), as well as between African states (Kihato, 2018).

Secondly and in consequence, the divergence between rhetoric and practice, thematic juxtaposition in the rhetoric as well as geographic commonalities also speaks to (hidden) interests. At the EU level, policies speak of regulating mobility whilst in reality they seek to restrict and prevent movement. As such, the rhetoric/practice gap can be used to achieve to contradictory goals of moving migration controls and prevention away from Europe's borders to the African continent, whilst strengthening the EU-African partnership at the same time (see also the predominance of partnership in 
the EU-African policy documents, Table 2). In Africa, recent research indicates that there is a preference for bilateral cooperation with the EU or member states on migration matters as more rapid, efficient and tailored to the countries interests and contexts (Castillejo, 2017, p. 10; Van Criekinge, 2016). Moreover, African states may be paying lip-service to European interests on securing borders in order to achieve leverage in an asymmetric relationship, but in practice purposively stall on implementation. Put differently, that the rhetoric was surprisingly similar can be explained by the overall asymmetric relationship between the two continents. As was shown when discussing the rhetoric on border management or dealing with trafficking, African partners are still very much dependent on donors for capacity building, equipment etc. (see also Van Criekinge, 2016). This makes a securitised rhetoric aligning with European migration governance aims of strategic interest. The consequences are two-fold both with on the one hand mobility regimes being dismantled in the name of security. This can be observed for the ECOWAS region for example, where mobility has become increasingly threatened by the emphasis of dealing with 'irregular migration' to Europe (De Haas, 2008). Many African governments have also reasserted more restrictive immigration regimes to the detriment of regional free movement initiatives (Kihato, 2018). On the other hand however, the dependence of the EU on African partners to successfully externalise their borders further south, gives African partners a new unique position where they can gain leverage in an otherwise asymmetric relationship. The African documents may contain certain buzzwords but there is no intention to follow up on the commitments made. Notably the partnership framework has thus far had little success, for example in Ethiopia the government has stalled on issuing travel documents for returnees, seeking greater funding for the reintegration of returnees (Castillejo, 2017). African stakeholders, well aware of the benefits of migration (even irregular) may be stalling on purpose (e.g. Raineri \& Rossi, 2017), whilst simultaneously paying lip-service to European interests. Future research should consider the national political interests in particular for African states (see also De Haas, 2008) and other relevant stakeholders.

If joint cooperation on migration is not taken seriously, this risks having a destabilizing effect on relationships between the two continents in the longer term. In addition to the overall asymmetric relationship and complexities between trade-offs of different multilateral levels (transnational/national), hidden interests of all the actors should not be underestimated.

\section{Endnotes}

${ }^{1}$ Though security can mean very different things and for example migration can be seen as an opportunity to improve economic security (see Raineri \& Rossi, 2017)

${ }^{2}$ There is no overall regional policy framework to govern migration in the Southern Africa Development Community or the East African Community though some plans and bilateral agreements exist (see also Kihato, 2018)

${ }^{3}$ All frequency counts were calculated in terms of average mentions per documents to one decimal point. All Boolean AND searches looked for two words within one sentence (e.g. legal and migration), see Table 2.

${ }^{4}$ Though policy makers often apply categorical differentiation between different types of migrants (i.e. labour migrants versus refugees or asylum seekers), this is 
problematic making a number of assumptions that often shy away from the complex realities of individual migrant journeys (Crawley \& Skleparis, 2018). This paper will consider refugees (and internally displaced persons) alongside other migrants, only differentiating when necessary.

${ }^{5}$ If we search for fight* OR combat*, it appears an average of 8.3 times in each EU-Africa documents compared to 5.1 times for the EU-only ones and only 3.6 times for the African ones, see Table

${ }^{6}$ The figures (from May 2017) used are those which have been committed, approx. $€ 1.7$ billion, which is higher than what has been contracted, approx. $€ 729.7$ million and actually disbursed, approx. €266.7 million (European Commission, 2017b).

${ }^{7}$ Since many of the projects have multiple goals they appear two or three or even four times. The funding was however split accordingly, though of course this is only a crude approximation. E.g. Project $\mathrm{N}^{\circ} 58$ (Programme to strengthen resilience and peaceful coexistence in Chad) is funded with $€ 18$ million and aims to address Goals 1, 2 and 4 and therefore $€ 6$ million was assigned to each category.

${ }^{8}$ Of the 31 projects 13 projects are aimed at setting up data collection and research observatories, but the Oxfam study shows that overall only $1.5 \%$ of the budget is allocated to research and monitoring (Oxfam, 2017).

\section{Additional files}

Additional file 1: Overview and Codes of Policy Documents. (DOCX $19 \mathrm{~kb}$ )

Additional file 2: Overview of EUTF Projects (May 2017). (DOCX 43 kb)

\section{Abbreviations}

ACP: African, Caribbean and Pacific Group of States; ECOWAS: Economic Community of West African States; EUTF: EU Emergency Trust Fund for Africa; GAMM: Global Approach to Migration and Mobility; IGAD: Intergovernmental Authority on Development; RECs: Regional Economic Communities

\section{Acknowledgements}

Previous versions of this paper were presented at the 7th European Conference on African Studies in Basel in June 2017 and the Annual Cross-Area e.V. Conference in Freiburg in November 2017. I thank Ulf Engel, Andreas Mehler and Cita Wetterich for comments on earlier versions and Verena Staiger and Julia Schuster for their research assistance. All errors remain my own.

\section{Funding}

I have not received any external funding for the collection of the material, the analysis or writing of this paper.

\section{Availability of data and materials}

A list of all the policy documents used for the content analysis as well as the list of EUTF projects can be found in Additional files 1 and 2 respectively. Data sharing not applicable to this article as no datasets were generated or analysed during the current study.

\section{Authors' contributions}

This paper is single-authored and I am solely responsible for the development, analysis and writing of the manuscript. The author read and approved the final manuscript.

\section{Authors' information}

Franzisca Zanker is senior research fellow at the Arnold-Bergstraesser-Institute at the University of Freiburg, where she heads a research cluster on (forced) migration. Her research interests include migration governance, citizenship and migration patterns in post-war contexts.

Competing interests

The author declares that she has no competing interests.

\section{Publisher's Note}

Springer Nature remains neutral with regard to jurisdictional claims in published maps and institutional affiliations. 
Received: 11 May 2018 Accepted: 22 January 2019

\section{Published online: 08 May 2019}

\section{References}

Andersson, R. (2016). Europe's failed 'fight' against irregular migration: Ethnographic notes on a counterproductive industry. Journal of Ethnic and Migration Studies, 42(7), 1055-1075.

Bisong, A. (2018). Trans-regional institutional cooperation as multilevel governance: ECOWAS migration policy and the EU. Journal of Ethnic and Migration Studies, 1-16. Advance online publication. https://doi.org/10.1080/1369183X.2018.1441607.

Bourbeau, P. (2015). Migration, resilience and security: Responses to new inflows of asylum seekers and migrants. Journal of Ethnic and Migration Studies, 41(12), 1958-1977.

Brachet, J. (2010). Blinded by security: Reflections on the hardening of migratory policies in central Sahara (IMI Working Paper Series, 26).

Carling, J., \& Hernández-Carretero, M. (2011). Protecting Europe and protecting migrants? Strategies for managing unauthorised migration from Africa. The British Journal of Politics \& International Relations, 13(1), 42-58.

Castillejo, C. (2016). The European Union Trust Fund for Africa: a glimpse of the future for EU development cooperation, (p. 22). Bonn: German Development Institute.

Castillejo, C. (2017). The EU Migration Partnership Framework: time for a rethink? (Discussion Paper No. 28/2017). Bonn: Deutsches Institut für Entwicklungspolitik.

Castles, S. (2004). Why migration policies fail. Ethnic and Racial Studies, 27(2), 205-227. https://doi.org/10.1080/ 0141987042000177306.

Clemens, M. A. (2014). Does development reduce migration? In R. E. B. Lucas (Ed.), International handbook on migration and economic development, (pp. 152-185). Cheltenham: Edward Elgar Publishing.

Collyer, M. (2016). Geopolitics as a migration governance strategy: European Union bilateral relations with southern Mediterranean countries. Journal of Ethnic and Migration Studies, 42(4), 606-624.

Crawley, H., \& Skleparis, D. (2018). Refugees, migrants, neither, both: Categorical fetishism and the politics of bounding in Europe's 'migration crisis'. Journal of Ethnic and Migration Studies, 44(1), 48-64.

Czaika, M., \& De Haas, H. (2013). The effectiveness of immigration policies. Population and Development Review, 39(3), 487-508.

De Haas, H. (2008). The myth of invasion: The inconvenient realities of African migration to Europe. Third World Quarterly, 29(7), 1305-1322.

European Commission. (2017a). Report from the commission to the European Parliament, the European council and the council: Fourth Progress Report on the partnership framework with third countries under the European agenda on migration (COM(2017) 350 final). Retrieved from https:/eeas.europa.eu/sites/eeas/files/4th_progress_report_partnership_ framework_with_third_countries_under_european_agenda_on_migration.pdf.

European Commission. (2017b). The EU Emergency Trust Fund for Africa - International Cooperation and Development European Commission.

Friedrich Ebert Stiftung / CCPAU. (2016). MIGRATION: IN IT FOR THE LONG RUN? (Africa - EU Policy Dialogue Platform Series). Addis Abeba: Friedrich-Ebert-Stiftung (FES), The Centre for Citizens' Participation in the African Union (CCPAU). Retrieved from http://library.fes.de/pdf-files/bueros/aethiopien/13073.pdf.

Flahaux, M.-L., \& De Haas, H. (2016). African migration: Trends, patterns, drivers. Comparative Migration Studies, 4. https://doi. org/10.1186/s40878-015-0015-6.

Hampshire, J. (2016). Speaking with one voice? The European Union's global approach to migration and mobility and the limits of international migration cooperation. Journal of Ethnic and Migration Studies, 42(4), 571-586.

IOM Press Release (2014). ACP observatory on migration highlights south-south migration and development. Brussels: International Organisation on Migration.

Kihato, C. (2018). The 'Containment Compact': The EU Migration'Crisis' and African Complicity in Migration Management (Occasional Paper No. 228). Johannesburg: South African Institute of International Affairs.

Lavenex, S., \& Kunz, R. (2008). The migration-development nexus in EU external relations. European Integration, 30(3), 439-457.

Mangala, J. (2013). Africa-EU Partnership on migration, mobility, and employment. In J. Mangala (Ed.), Africa and the European union, (pp. 195-222). New York: Palgrave Macmillan.

MEDAM (2018). Flexible Solidarity: A comprehensive strategy for asylum and immigration in the EU (2018 MEDAM assessment report on asylum and migration policies in Europe). Kiel: Mercator Foundation.

Nijenhuis, G., \& Leung, M. (2017). Rethinking migration in the 2030 agenda: Towards a de-territorialized conceptualization of development. Forum for Development Studies, 44(1), 51-68.

Oxfam (2017). An emergency for whom? The EU Emergency Trust Fund for Africa - migratory routes and development aid in Africa (Oxfam briefing note). Oxfam International. Oxford: Oxfam. Retrieved from https://www-cdn.oxfam.org/s3fs-public/ file_attachments/bp-emergency-for-whom-eutf-africa-migration-151117-en_1.pdf.

Raineri, L., \& Rossi, A. (2017). The security-migration-development Nexus in the Sahel: A reality check. Rome: Istituto Affari Internazionali.

Rother, S., \& Piper, N. (2015). Alternative regionalism from below: Democratizing ASEAN's migration governance. International Migration, 53(3), 36-49.

Rwamatwara, E. (2005). Forced migration in Africa: a challenge to development. Stichproben - Wiener Zeitschrift Für Kritische Afrikastudien, Nr. 8, (pp. 173-191). Retrieved from https://stichproben.univie.ac.at/fileadmin/user_upload/p_stichproben/ Artikel/Nummer08/10_Rwamatwara.pdf.

Van Criekinge, T. (2016). The limits of the EU's external dimension of migration in Africa. In M. Carbone (Ed.), The European Union in Africa: Incoherent policies, asymmetrical partnership, declining relevance? (pp. 258-282). Manchester: Manchester University Press.

Völkel, J. C. (2014). Money for nothing, the cricks for free. Comparative Migration Studies, 2(2), p. 151.

Welz, M. (2015). The roles of the African union and its member states in managing migration across the Mediterranean. In F. Ippolito, \& S. Trevisanut (Eds.), Migration in the Mediterranean: Mechanisms of international cooperation, (pp. 94-114). Cambridge: Cambridge University Press.

Witt, A., \& Both, L. (2016). Partnerschaft auf tönernen Füßen (Standorte No. 4/16) [Partnership with Clay Feet]. Frankfurt: LeibnizInstitut Hessische Stiftung Friedens-und Konfliktforschung. 